\title{
EFFECT OF ANAESTHETIC TECHNIQUES IN MIGRATION AND APOPTOSIS MDA-MB-231 \\ TUMOR CELLS “IN VITRO”, IN BREAST CANCER SURGERY
}

Morís Stal, *. Casssinello F. **; López V. *Fundacion Jimenez Diaz University Hospital, Madrid; **Nuestra Señora de Candelaria University

\section{MASTECTOMY SURGERY}

\begin{tabular}{|l|c|c|c|}
\hline & SGA & PBI & $p$ \\
\hline AGES (year) & 56,75 & 65,25 & 0,468 \\
\hline WEIGHT (BMI) & 28,75 & 26,87 & 0,384 \\
\hline $\begin{array}{l}\text { POSITIVE } \\
\text { SENTIONAL } \\
\text { NODE }\end{array}$ & 1 & 2 & 1,000 \\
\hline $\begin{array}{l}\text { AXILLARY NODE } \\
\text { CLEARANCE }\end{array}$ & 1 & 2 & 1,000 \\
\hline $\begin{array}{l}\text { OESTROGEN } \\
\text { RECEPTOR } \\
\text { POSITIVE }\end{array}$ & 4 & 4 & 1,000 \\
\hline $\begin{array}{l}\text { PROGESTERONE } \\
\text { RECEPTOR } \\
\text { POSITIVE }\end{array}$ & 3 & 4 & 1,000 \\
\hline \begin{tabular}{l} 
HER2 (POSitive) \\
\hline FISH (amplified)
\end{tabular} & 0 & 0 & 0 \\
\hline $\begin{array}{l}\text { SURGERY TIME } \\
\text { (min) }\end{array}$ & 133,75 & 113,75 & 0,884 \\
\hline $\begin{array}{l}\text { RECOVERY TIME } \\
\text { (min) }\end{array}$ & 112,5 & 131,25 & 0,659 \\
\hline
\end{tabular}

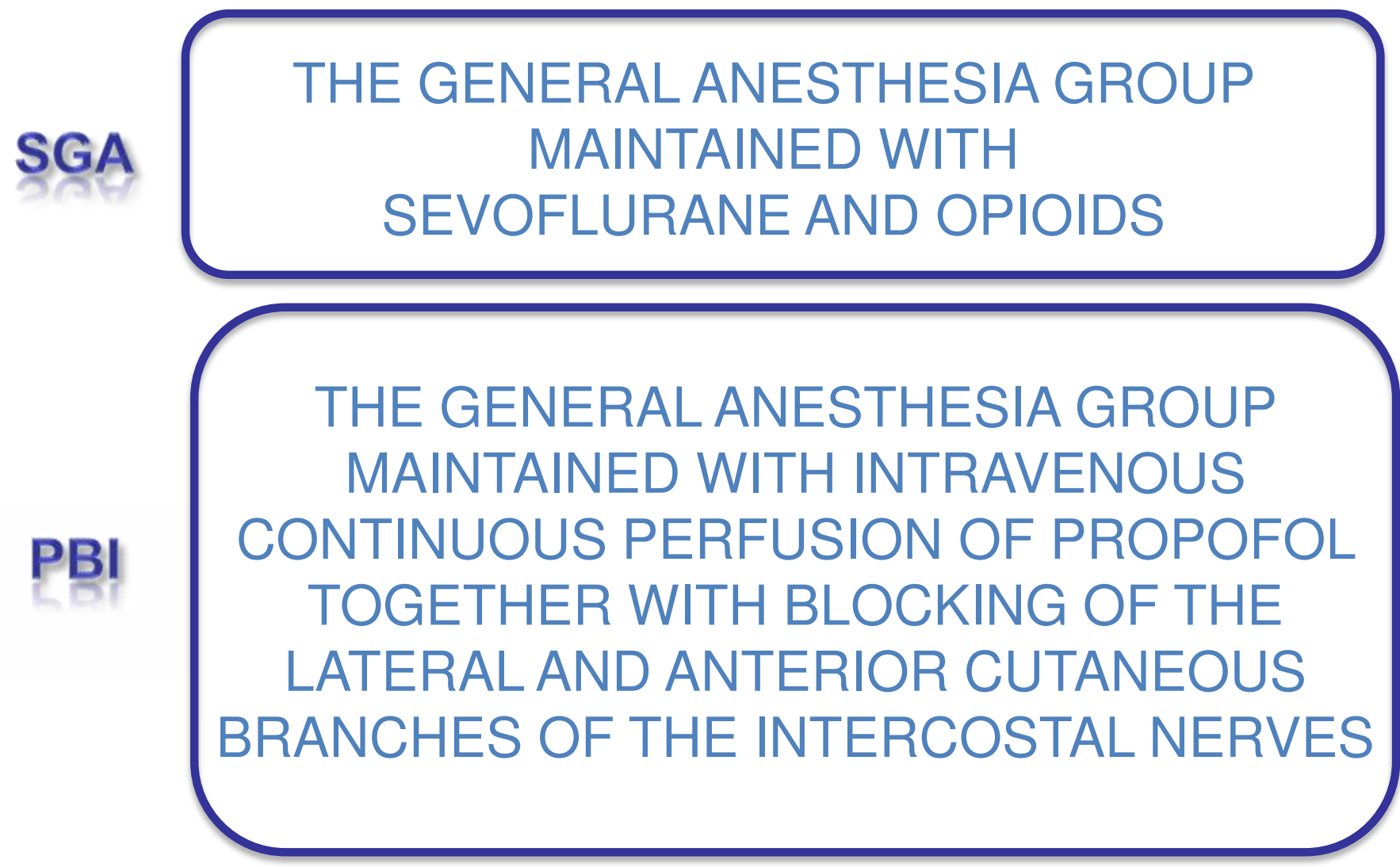

MIGRATION CELL

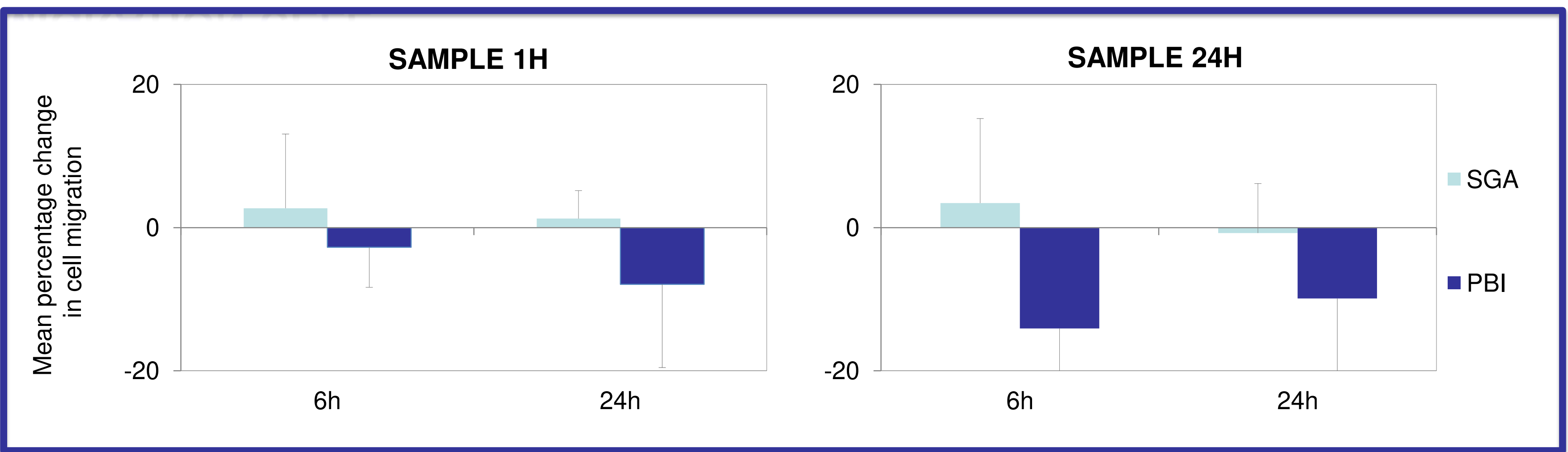

APOPTOSIS CELL

Slower migration was observed in both samples of the PBI group in the 1st postoperative hour (6h: $-2.7 \%$ vs $2.7 \%, p=0.56 ; 24 \mathrm{~h}:-7.92 \%$ vs $1.26 \%, p=0.149)$ and greater in the postoperative 18-24h (6h: $-14.1 \%$ vs $3.42 \%, p=0.08$; $24 h:-9.91 \%$ vs $-0.76 \%, p=0.38$ )

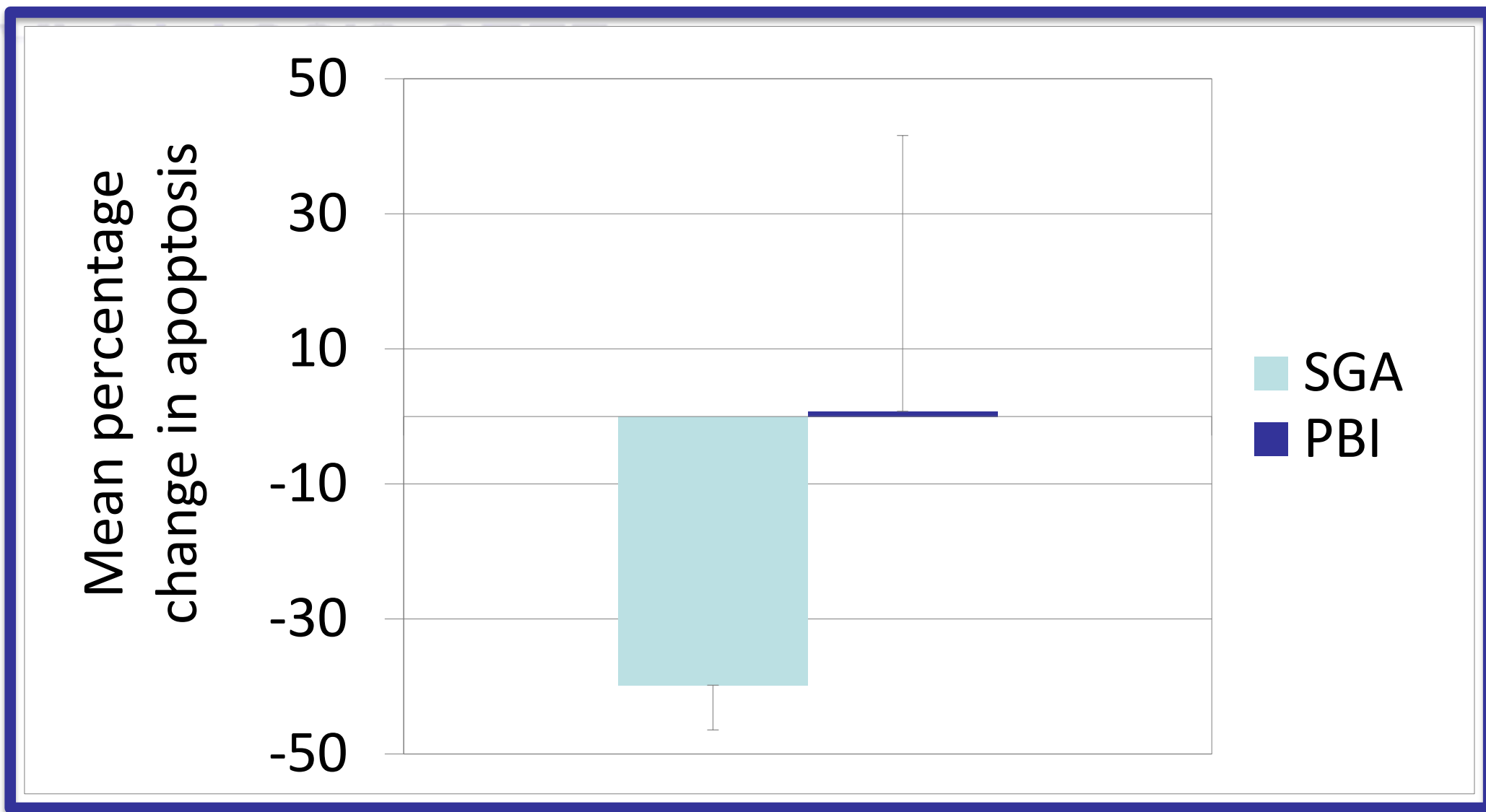

C. A. Deegan, D. Murray, P. Doran, P. Ecimovic, D. C. Moriarty, and D. J. Buggy, "Effect of anaesthetic technique on oestrogen receptor-negative breast cancer cell function in vitro.," Br. J. Anaesth., vol. 103, no. 5, pp. 685-90, 2009.

A. I. Jaura, G. Flood, H. C. Gallagher, and D. J. Buggy, "Differential effects of serum from patients administered distinct anaesthetic techniques on apoptosis in breast cancer cells in vitro: a pilot study," Br. J. Anaesth., vol. 113, no. suppl 1, pp. i63-i67, 2014.

Apoptosis was reduced in postoperative 18-24h of SGA serum compared with their preoperative values $(-39.8 \%)$ with a level close to significance ( $p=$ 0.068). There were no changes in apoptosis with serum from the PBI group $(0.75 \%, p=1)$ and there was no significant difference between both groups $(p=0.149)$

\section{CONCLUSION:}

This outcomes implies that anaesthetic technique might affect the serum environment that impacts cancer cell funtion. 